\title{
Measuring current consumption of locally grown foods in Vermont: Methods for baselines and targets
}

\author{
David Conner, ${ }^{a}$ University of Vermont \\ Florence Becot, ${ }^{\mathrm{b} *}$ University of Vermont \\ Doug Hoffer, ${ }^{\mathrm{c}}$ Policy Analyst \\ Ellen Kahler, ${ }^{\mathrm{d}}$ Vermont Sustainable Jobs Fund \\ Scott Sawyer, ${ }^{\mathrm{d}}$ Vermont Sustainable Jobs Fund \\ Linda Berlin, ${ }^{\mathrm{e}}$ UVM Center for Sustainable Agriculture and Co-Chair, Sustainable Agriculture Council
}

Submitted September 26, 2012 / Revised December 17, 2012, January 25, January 28, and February 20, 2013 /

Accepted February 20, 2013 / Published online May 17, 2013

Citation: Conner, D., Becot, F., Hoffer, D., Kahler, E., Sawyer, S., \& Berlin, L. (2013). Measuring current

consumption of locally grown foods in Vermont: Methods for baselines and targets. Journal of Agriculture, Food

Systems, and Community Development, 3(3), 83-94. http://dx.doi.org/10.5304/jafscd.2013.033.004

Copyright (C) 2013 by New Leaf Associates, Inc.

\author{
Abstract \\ Numerous studies have measured the economic \\ impact of increased consumption of locally grown \\ ${ }^{a}$ Department of Community Development and Applied \\ Economics, University of Vermont, 205H Morrill Hall, \\ Burlington, Vermont 05405 USA \\ b Center for Rural Studies, University of Vermont, 206 Morrill \\ Hall, Burlington, Vermont 05401 USA \\ c 161 Austin Drive, \#71, Burlington, Vermont 05401 USA \\ d Vermont Sustainable Jobs Fund, 3 Pitkin Court, Suite 301e, \\ Montpelier, Vermont 05602 USA \\ e UVM Center for Sustainable Agriculture and Co-Chair, \\ Sustainable Agriculture Council, 109 Carrigan Drive, \\ Burlington, Vermont 05405 USA \\ * Corresponding author: Florence Becot; +1-802-656-9897; \\ fbecot@uvm.edu
}

Volume 3, Issue 3 / Spring 2013 foods, and many advocates have set goals for increasing consumption of locally grown foods to a given percentage. In this paper, we first apply previously developed methods to the state of Vermont, to measure the quantity and value of food that would be consumed if the USDA Dietary Guidelines were followed. We also assess the potential of locally grown foods to meet these

Conflict of interest statement: This material is based upon work supported by the Cooperative State Research, Education, and Extension Service, U.S. Department of Agriculture, under Award No. 2010-34269-20972. The research work was done in collaboration with all the co-authors on the article. UVM affiliates did not have a contractual relationship with the Vermont Sustainable Job Funds. Any opinions, findings, conclusions, or recommendations expressed in this publication are those of the author(s) and do not necessarily reflect the views of the U.S. Department of Agriculture. 
guidelines, finding that meeting dietary guidelines with a local, seasonal diet would bring economic benefit, in this case, US $\$ 148$ million in income for Vermont farmers. A missing piece of information has been: what is the current percentage of locally grown food being consumed in a given city, state, or region? The Farm to Plate Strategic Plan, a 10year plan for strengthening Vermont's food system, attempted to answer this question. To date, we know of no credible set of methods to precisely measure the percentage of food consumed that is locally grown. We collect data from a variety of sources to estimate current local consumption of food. We were able to measure and account for about US $\$ 52$ million in local food expenditures, equal to about $2.5 \%$ of all food expenditures in Vermont. We then discuss limitations and suggestions for improving measurement methods moving forward.

\section{Keywords}

consumption, economic benefits, local food, measuring methods

\section{Introduction and Literature Review}

Eating locally grown food has become quite popular in recent years. In 2007, the word "locavore" was named the "Oxford Word of the Year" (Oxford University Press, 2007). The cause of eating locally is championed by well-known authors in the popular press (Kingsolver, 2007; Pollan, 2008). Scholars have also expressed interest in the potential benefits of eating locally as part of a sustainable or community-based food system (Feenstra, 2002; Hinrichs, 2003). Among the purported benefits of increasing consumption of locally grown foods are improved farm profitability and viability, farmland conservation, improved public health, and closer social ties between farmers and consumers (Andreatta \& Wickliffe, 2002; Conner, Colasanti, Ross, \& Smalley, 2010; Conner \& Levine, 2006; Lyson, 2004). Selling locally grown food is a strategy that allows small and medium-sized farms to differentiate their products in the marketplace. These same farms also contribute to a broad array of indicators of social, economic and environmental well-being (Kirschenmann, Stevenson, Buttel, Lyson, \&
Duffy, 2008; Lobao, 1990; Lyson \& Welsh, 2005). Community-based food systems can engage diverse stakeholders with many different motivations, although some scholars caution against associating "local" with all things virtuous (Bellows \& Hamm, 2001; Born \& Purcell, 2006; Conner, Cocciarelli, Mutch, \& Hamm, 2008; Oglethorpe, 2008; Wright, Score, \& Conner, 2008).

As interest in the social, health, environmental, and, in particular, farm- and community-based economic benefits of local food consumption has grown, the state of Vermont passed legislation to create the Farm to Plate Strategic Plan, a 10-year plan for strengthening Vermont's food system. Vermont's food system (with elements including nutrient management, farm inputs, production, processing, distribution, wholesaling, and retailing) is an important driver of economic prosperity and job creation in the state, estimated to include 57,089 jobs ( $16 \%$ of all private-sector jobs) at 6,984 farms and 4,104 other food-related businesses (13\% of all private-sector establishments) (Vermont Sustainable Jobs Fund, 2012). Total output from food production in the state is estimated at US\$2.7 billion (Vermont Sustainable Jobs Fund, 2011). The Farm to Plate Strategic Plan contracted with a consultant to conduct an economic impact analysis using the economic forecasting software REMI. The model estimated that increasing instate production by $5 \%$ (over an assumed $5 \%$ baseline) over 10 years would result in the creation of about 1,700 new private-sector jobs in the food system, along with an additional US $\$ 213$ million in economic output annually (Vermont Sustainable Jobs Fund, 2012).

This study attempts to create baseline measures for the Farm to Plate Initiative. Specifically, it measures current consumption and upper bounds for consumption under specific dietary scenarios. To be clear, it does not advocate for Vermont farmers growing exclusively for local markets. Rather, it attempts to understand the current situation around local food consumption in Vermont and to estimate how much local food could be consumed, with an eye toward informing efforts to foster more local food consumption and its concomitant community and economic benefits. We begin by asking the following questions: what 
quantities of foods do Vermonters eat (under two dietary scenarios); and what volumes (in dollar value and acreage) are needed to meet these diets with a locally grown, seasonal diet? Following this, we present methods and results for actual current consumption.

Many Vermonters are interested in the extent to which the state can feed itself through local food production. Many advocates have set goals for increasing consumption of locally grown foods to a given percentage. Unfortunately, no comprehensive data exist to indicate exactly how much and what types of food Vermonters are currently consuming. We lack methods for determining the current percentage of locally grown food being consumed in a given city, state, or region. One objective of this study is to quantify the amount of locally produced food that has been consumed by Vermonters, using the best available data sources.

\section{Previous Assessments of Local Demand}

Many studies of local food have focused on the demand side of the equation, identifying drivers of demand, and demographic, psychographic, and behavioral attributes of local food consumers (Bean Smith \& Sharp, 2008; Brown, 2003; Conner, Colasanti, et al., 2010; Ostrom, 2005; Thilmany, Bond, \& Bond, 2008; Zepeda \& Leviten-Reid, 2004; Zepeda \& Li, 2006). Key drivers of demand include geographic proximity, relationships with farmers, and support for local economies.

\section{Assessments of Production}

Given the magnitude of the global agri-food system, some observers, such as Meter and Rosales, (2001), bemoan the lost opportunity for community economic development when food production and consumption are disconnected. In light of this, a number of studies have looked at the capacity of a given region or state to supply its own food and the potential economic impacts of increased consumption of local food under different dietary scenarios. A series of studies from Cornell University finds that New York state could provide $34 \%$ of its total food needs (with rural upstate regions predictably being more self-sufficient than New York City), and that dietary intake influences the acreage needed to meet human consumption needs (Peters, Bills, Lembo, Wilkins, \& Fick, 2009; Peters, Wilkins, \& Fick, 2007).

\section{Import Substitution and Dietary} Scenario Measurements

Other studies look at the economic impact of meeting local food consumption targets. Using the Impact Analysis for Planning economic impact modeling system (IMPLAN) input-output model, an Iowa State University researcher modeled the impact of meeting United States Department of Agriculture (USDA) dietary guidelines with Iowagrown fresh produce for one-quarter of the calendar year, finding that this change would sustain, either directly or indirectly, US $\$ 462.7$ million in total economic output, US\$170 million in total labor income, and 6,046 total jobs in Iowa (Swenson, 2006). A similar study, which looked at potential impacts of increased fruit and vegetable production for local consumption in a six-state region of the upper Midwest, found that more than a billion dollars in income and nearly 10,000 jobs would result (Swenson, 2010). A study in Michigan used the IMPLAN model to measure job and income impacts of meeting public health dietary recommendations with locally grown fruits and vegetables (Conner, Knudson, Hamm, \& Peterson, 2008). In all cases, the models suggest large increases in income to farmers and in job creation, even accounting for the opportunity costs of transitioning field crop acreage into produce production.

A key limitation of the above studies (Meter \& Rosales, 2001; Peters, Bills, et al., 2009; Peters, Wilkins, et al., 2007; Conner, Knudson, et al., 2008; Swenson, 2006; 2010) is that they all measure the outcome or impact of hypothetical changes: what would happen if some consumption pattern were to change. An obvious gap in the literature is how much locally grown food is actually being consumed. One place to start this calculation is with upper and lower bounds.

\section{Upper and Lower Bounds}

Timmons, Wang, and Lass (2008) demonstrated a method for calculating the upper bound for the proportion of locally grown food in a given state or region. Their research measured the ratio of per 
capita consumption (i.e., disappearance) of a given crop or crop category divided by per capita consumption. Their results for Vermont show that for some crops and products, most notably dairy, production far exceeds consumption, while for fruits and vegetables, Vermont can only produce a fraction ( $25 \%$ and $36 \%$, respectively) of what is consumed instate. Their calculations did not take into consideration dietary requirements or seasonality. This figure also omits the proportion of food that is grown in Vermont and consumed elsewhere (likely to be relatively small for produce, but very large for dairy). By comparison, using data from the Consumer Expenditure Survey and Vermont Department of Taxes, we estimate that US $\$ 2.7$ billion is spent on food annually in Vermont by residents and nonresident tourists, including both at-home and away-from-home consumption, (United States Department of Labor, 2010; Vermont Department of Taxes, 2010).

A possible lower bound for the proportion of local food is the USDA National Agricultural Statistics Service (NASS) figure of food sold directly to consumers, which is available in the Census of Agriculture (USDA, 2007). This figure does not distinguish between direct sales made to Vermont residents and out-of-state residents. Also, at least one study suggests that NASS undercounts the true value of direct food purchases (Conner, Smalley, Colasanti, \& Ross, 2010). Similar undercounting was found in another study. The 2008 Organic Production Survey (OPS) reported sales at a higher level than the 2007 Census, while the OPS survey reported data from fewer farms (Hunt \& Matteson, 2012). Furthermore, Lev and Gwin (2010) argue that the counting of direct-marketing sales is difficult and not well understood.

\section{Methods and Results}

\section{Estimation of Current and Target Consumption Patterns in Vermont}

This estimate uses methods developed by Conner, Knudson, et al. (2008) and Abate, Conner, Hamm, Smalley, Thomas, and Wright (2009) to measure the current consumption of fruits, vegetables, dairy, and proteins in Vermont (regardless of source), as well as the levels of consumption if
USDA dietary guidelines were followed. We chose these as a dietary benchmark as they are well known and permit relatively easy replication of our methods. We recognize the dietary guidelines' contested and politicized nature and therefore make no claim, for or against, that they truly guide optimal consumption. For products that can be grown in Vermont, yield and price data (primarily from USDA, as used by Conner et al., 2008, and Abate et al., 2009) are used to calculate the number of acres that would be needed and the revenue farmers would receive. The basic questions leading the analysis are as follows:

1. How many servings of fruits, vegetables, proteins and dairy should Vermonters consume according to USDA dietary guidelines? This is subsequently called the "Recommended" diet.

2. Assuming Vermonters' consumption patterns mirror those of the United States as a whole (according to USDA consumption data), how many servings of each do they actually eat? This is subsequently called the "Average" diet.

3. If Vermonters met these two diets with locally grown foods, as much as is practical given climate and land availability, how many acres would be required to produce them at current yield levels and, given prevailing prices, how much revenue would this generate for Vermont farmers?

\section{Estimating the Average Vermont Diet}

To calculate consumption patterns under the Average diet, we multiplied daily per capita consumption figures for vegetables, fruits, dairy, and proteins compiled by the USDA Economic Research Service (ERS) by Vermont's population (from the US Census) and 365 days to calculate the state annual consumption, using US Census data (USDA, 2011). The key assumption was that Vermonters' consumption patterns mirror those of the nation as a whole. At least one study (United Health Foundation, 2011) suggests that Vermonters eat more fruits and vegetables than any other states' residents, so the figures for the Average diet may be considered a lower bound. Then, using age-sex population figures and the recommended amount of food in each category for 
Table 1. Annual Consumption for Vermont: Average and Recommended

\begin{tabular}{lcccccc}
\hline & $\begin{array}{c}\text { USDA } \\
\text { recommended } \\
\text { consumption per } \\
\text { day per person } \\
\text { (Recommended } \\
\text { diet) }\end{array}$ & $\begin{array}{c}\text { Estimated } \\
\text { consumption per } \\
\text { day per person } \\
\text { (Average diet) }\end{array}$ & $\begin{array}{c}\text { consumption per } \\
\text { vear for Vermont } \\
\text { (Recommended } \\
\text { diet) }\end{array}$ & $\begin{array}{c}\text { USDA } \\
\text { Vermont } \\
\text { consumption } \\
\text { per year } \\
\text { (Average diet) }\end{array}$ & $\begin{array}{c}\text { Recommentio of } \\
\text { to Average diet }\end{array}$ & $\begin{array}{c}\text { Net change } \\
\text { between } \\
\text { Average and } \\
\text { Recommended } \\
\text { diets }\end{array}$ \\
\hline Fruit (cups) & 2 & 0.84 & $425,576,008$ & $190,416,042$ & 2.23 & $+235,159,966$ \\
\hline Vegetables (cups) & 3 & 1.67 & $606,848,270$ & $379,790,725$ & 1.60 & $+227,057,545$ \\
\hline $\begin{array}{l}\text { Protein } \\
\text { (oz. equivalent) }\end{array}$ & 6 & 6.6 & $1,259,701,809$ & $1,498,126,462$ & 0.84 & $-238,424,653$ \\
\hline Dairy (cups) & 3 & 1.68 & $656,543,993$ & $382,372,493$ & 1.72 & $+274,171,500$ \\
\hline
\end{tabular}

Table 2. Revenue and Acreage Required for Current and Recommended Diets

\begin{tabular}{|c|c|c|c|c|c|c|c|c|}
\hline Food category & $\begin{array}{c}2007 \text { total sales } \\
\text { in US\$ }\end{array}$ & $\begin{array}{c}\text { Recommended } \\
\text { diet revenue in } \\
\text { US\$ }\end{array}$ & $\begin{array}{l}\text { Average diet } \\
\text { revenue, in US\$ }\end{array}$ & $\begin{array}{l}\text { Change } \\
\text { between } \\
\text { Recom- } \\
\text { mended diet } \\
\text { revenue and } \\
\text { total sales, \% }\end{array}$ & $\begin{array}{l}2007 \text { total } \\
\text { acres }^{\mathrm{a} b}\end{array}$ & $\begin{array}{l}\text { Recom- } \\
\text { mended diet } \\
\text { acres } \\
\text { needed }^{\mathrm{b}}\end{array}$ & $\begin{array}{l}\text { Average diet } \\
\text { acres } \\
\text { needed }^{\mathrm{b}}\end{array}$ & $\begin{array}{c}\text { Change } \\
\text { between } \\
\text { Recommended } \\
\text { diet acreage } \\
\text { and total } \\
\text { current acres, } \\
\text { in } \%\end{array}$ \\
\hline Fruit & $15,875,000$ & $6,074,743$ & $2,718,031$ & -61.7 & 4,252 & 2,083 & 932 & -51.0 \\
\hline Vegetables & $13,192,000$ & $16,782,605$ & $10,503,248$ & +27.2 & 2,855 & 3,677 & 2,301 & +28.8 \\
\hline Protein & $73,125,000$ & $87,341,045$ & $103,872,147$ & +19.4 & 153,132 & 292,950 & 348,397 & +91.3 \\
\hline Dairy & $493,926,000$ & $38,244,347$ & $22,273,582$ & -92.2 & 539,371 & 123,816 & 72,111 & -77.0 \\
\hline Total & $596,118,000$ & $148,442,741$ & $139,367,007$ & -75.1 & 708,239 & 422,526 & 423,741 & -40.3 \\
\hline
\end{tabular}

a USDA Census of Agriculture (USDA, 2009). $\quad$ b 1 acre $=0.40$ hectare

each age-sex group, we calculated the recommended amount of food per year (table 1). It is assumed that two-thirds of Vermonters are sedentary and one-third are active, according to the USDA definition, an assumption previously used by Conner, Knudson, et al. (2008). Finally, we calculated the ratios of the Recommended to Average diets by dividing Recommended by Average diet figures. Consistent with previous research (Abate et al., 2009), Vermonters should eat roughly twice as much fruits, half again as much vegetables, and about $16 \%$ less proteins than they currently do. The net change at the state level is found in table 1.

Next, we calculated current annual consumption of individual fruit, vegetable, proteins, and dairy products (per capita consumption times state populations) for the Average diet. These figures were multiplied by the Recommended to Average ratio in table 1 for the figures listed in the Recommended diet. We assumed that all meat (beef, pork and chicken), 20 vegetables, and 12 fruits can be grown in Vermont. Following methods developed by Conner, Knudson, et al. (2008) and Abate et al. (2009), the seasonal availability of fruits and vegetables was taken from a Michigan State University Extension (2004) publication. We assumed that locally grown fruits and vegetables are only available at these times. Given Vermont's short growing season, we assume Vermont's seasonal availability of vegetables is $80 \%$ that of Michigan's. ${ }^{1}$ We used price data and yield data from Conner, Knudson, et al. (2008) and Abate et al. (2009), primarily based on USDA NASS and ERS data, to calculate the revenue generated and acres needed if current and recommended consumption levels were met, when available, with Vermont-grown foods (table 2). Note that these are total acres needed, not additional acres of production. Note also that, as assumed in Conner, Knudson, et al., 2008, if fruit

\footnotetext{
1 As of 2012, Vermont is in Agricultural Hardiness Zones $3 a-4 b$, while Michigan is in zones $4 b$ to $6 b$. See http://planthardiness.ars.usda.gov/PHZMWeb/
} 
and vegetable consumption were increased to Recommended levels, Vermonters would increase consumption proportionally. Specifically, for the example of fruit, in aggregate Vermonters eat 2.23 times as many items that grow in Vermont — like apples - as well as items, which do not — like bananas. This assumes that consumer tastes remain consistent: people who like apples eat more apples, and so on. Last, comparing total sales data with revenue from the Recommended diet, we find that currently Vermont is producing more fruits and dairy than the state population needs for the Recommended diet, while it does not produce enough vegetables and protein. This finding has potential economic and political implications that we will address in the discussion section.

\section{Methods and Results for Estimating Actual Current Consumption of Local Food}

We utilized secondary data from two government sources. We used U.S. Census non-employer data (United States Department of Commerce, 2009) for food manufactured in Vermont by small-scale businesses, and USDA NASS (USDA, 2007) figures measuring food sales direct to consumers. We also made direct inquiries to several types of stakeholders to fill data gaps:

- Institutional food service operations that purchase and serve locally grown foods, including K-12 schools, colleges and universities and hospitals. This was done in a number of ways, including by direct inquiry to the food service director, via local food hubs, statewide nonprofits, and school-led buying cooperatives;

- Statewide nonprofit organizations that conduct surveys on sales to farmers' markets, community supported agriculture (CSA) operations, and restaurants;

- Produce distributors and food hubs;

- Retailers (mainstream grocery, food cooperatives and natural food stores); and

- State government.

In each case, members of the research team asked for their total 2010 sales of locally grown foods. The data were then analyzed by the team for credibility and to detect and eliminate double counting. For example, we looked at purchase figures from a hospital and subtracted out certain purchases that were characterized as "local" but had no local content (e.g., soda). In addition, we avoided double counting by looking at both reports from institutional buyers and wholesalers known to sell to them, subtracting out those figures as well, crediting these figures only to the hospital rather than the distributor.

We received no data from several key sources, including Vermont's three major retail grocery store chains. It is not clear whether these sources are unwilling (they believe the data is proprietary and confidential) or unable (they do not track local products in a way which makes reporting possible) to provide such data. In 2013, efforts will be made to collect additional data from locally owned, independent grocers, and food service companies operating in Vermont's colleges and universities.

\section{Table 3: Summary of Results}

\begin{tabular}{lrl}
\hline Category & \multicolumn{1}{c}{ Total (US\$) } & Source \\
\hline Direct Sales & $\mathbf{2 4 , 7 3 9 , 2 7 3}$ & Census of Agriculture \\
Small Food Manufacturers & $9,825,340$ & U.S. Census Bureau non-employer statistics \\
Chefs / Restaurants & $8,483,475$ & Vermont Fresh Network \\
Coop Grocers & $6,100,000$ & Multiple sources \\
Higher Education & $1,448,915$ & Response from buyers \\
Hospitals & 800,000 & Response from buyers \\
Farm to School & 180,860 & Vermont Farm to School Network \\
State Government & 172,327 & Response from suppliers \\
\hline
\end{tabular}


The early protocols and a report of preliminary findings were shared with the project advisory committee, consisting of scholars and practitioners well-known for their interest and expertise in this area, namely Mike Hamm and Rich Pirog of Michigan State University, Christian Peters of Tufts University, and Ken Meter of the Crossroads Resource Center. Many of the ideas in the discussion were generated in conversations and communications with them.

Results of our inquiries are presented in table 3.

\section{Discussion}

\section{Estimation of Current and Target Consumption Patterns in Vermont}

We found that in order to meet the dietary guidelines, Vermonters need to increase their consumption of fruits, vegetables, and dairy while decreasing their consumption of meat. These dietary changes provide the Vermont agricultural sector with potential new markets. When looking at the current level of production in the state, we found that the state produces more than enough fruits and dairy to meet the Recommended diet, but not enough vegetables and protein. Our findings, particularly concerning fruit consumption and production, differ from those of Timmons et al. (2008) in part because our analysis focused on locally and seasonally available products.

Based on these findings, at least two scenarios emerge. First, a state could devote all resources only to feeding its own people - a type of autarky. In this scenario in Vermont, dairy and fruit production would need to be scaled down, leaving the state with excess capacity, and concomitant loss of revenue and employment in these sectors, while production of protein and vegetables would have to be scaled up. This scenario would require major restructuring and would likely be both politically and economically untenable.

In another scenario, each state could coordinate with others in the region, with each pursuing a more localized and regionalized diet. Such coordination would allow access to regional markets and create a smoother transition for the regional agricultural economy. It would be important for other states to conduct a similar kind of analysis in order to inform future allocation and align food system development with local communities' goals, such as economic development, nutritionally improved diets, and around those products which are best suited for the soils, climate, land base, and existing infrastructure of a given state in the region.

Though extreme, these scenarios highlight the need for collaboration between states at least at the regional level. Collaboration should take place not only at the planning level, but also at the production, processing, and distribution levels. Suggestions for collaboration in terms of data needs and research is highlighted in the paragraph below.

\section{Estimating Actual Current Consumption of Local Food}

Our estimate of about US $\$ 52$ million makes up a small percentage $(2.5 \%)$ of Vermont's US $\$ 2$ billion total food bill. We had a great deal of cooperation from many partners and agencies in this research, but still lack data of a potentially large magnitude from a few sources. Nationally, the largest purveyors of local food are distributors and retailers (Low \& Vogel, 2011), so their lack of response is significant. At this time, most see too little (or no) benefit and/or too high a cost in reporting these figures. Given current food safety protocols, they are able to trace back foods to the farm of origin in case of a recall, but they may consider it too costly to measure local food sales as a routine practice. Methods must be developed which either automatically gather this information or circumvent the need for it. Below we discuss the limitations of our study and potential strategies for overcoming them.

\section{Limitations and Strategies}

Regardless of what strategies are used, we have identified many lingering issues that need to be addressed.

- What is local? How is it defined? The Farm to Plate Initiative defines local as food produced from Vermont plus within a 30 mile radius of state borders. State boundaries are used in many other contexts. One Vermont-based distributor defines local as the region it serves, that is, where its trucks go. Should a single definition be used by all 
investigators? Which definition should be used and why? State boundaries would be an obvious choice, both for clarity and to build on existing state promotion efforts.

- Similarly, where in the supply chain should the data be measured? At the farm gate: what distributors or wholesalers pay to farmers? What foodservice or retail buyers pay to distributors? What end consumers pay to the retailer or foodservice operation? Collecting data directly from farmers, as discussed above, would address this problem, but places a large burden on farmers. On the other hand, assuming they can be adequately compensated and equipped to do so, data collection would also serve as a means to triangulate traceability protocols (tracing forward as well as back). Furthermore, it would permit input-output analyses based on increased farm income like those discussed above (Conner, Knudson, et al., 2008; Swenson, 2010).

- Double counting is a challenge. If we were to get data from both distributors and their buyers, how can we be sure to subtract out duplicate purchases? Again, measuring at the farm level would address this, assuming adequate compensation and mechanisms are provided.

- If we are to count food products (e.g., jams, baked goods, and sauces) processed locally, how do we account for ingredient foods grown elsewhere? The Farm to Plate Initiative defines as local those value-added food products that are processed in Vermont with ingredients grown in Vermont or within a 30 mile radius (Vermont Sustainable Jobs Fund Aggregation \& Distribution Working Group, 2012; Vermont Sustainable Jobs Fund, 2011). The Michigan Good Food Charter requires 50\% local ingredients (Colasanti et al., 2010). Should a single standard be used, and if so, which one? Furthermore, sourcing of products can change depending on the time of the year. How should this be addressed? Again, measurement at the farmgate level would address these issues.
- Fluid milk may be difficult to trace back to a single farm, given the degree to which it is pooled from multiple farms. How can this counted with accuracy?

- With increased attention to the capacity and prospects for regional food systems, interstate cooperation, notably harmonization of standards and definitions, will be needed to conduct these types of studies on regional scales. Vermont's Farm to Plate Initiative and Michigan's Good Food Charter are two prominent examples from which to start.

Based on our work so far, we foresee the following opportunities and obstacles for a more comprehensive and accurate count. Potential strategies include:

- Work with agencies already collecting data from farmers to get information directly from farmers. One promising idea is to work with the state or regional National Agricultural Statistics Service, as it is capable of developing and administering surveys with high response rates at affordable rates (M. Hamm, personal communication, June 12, 2012). One method would be to ask for total farm sales revenue, and then to list percentages sold to various market channel categories (summing to $100 \%$ ). As emphasized above, care must be made, however, to avoid putting all the data collection burden on farmers without consideration of their time. Hunt and Matteson (2012) made a few suggestions in a recent paper: engage farm stakeholders during census survey development, improve question specificity to reduce reporting ambiguities, introduce questions based on marketing channel usage, and track market-level characteristics of different market channels.

- Hunt and Matteson's (2012) suggestions may be operationalized best by forming a community of practice (COP) around measuring local foods. This may involve participatory action research to develop goals and discover perceived benefits and barriers. Pos- 
sible roles for researchers and practitioners within a COP approach may include:

○ Helping purveyors develop standard stock keeping units (SKU) systems for local produce, sharing best practices and experiences among the group;

- Providing resources and technical assistance to their efforts; and

- Developing, testing, and refining methods for data collection. In particular, if farmers are to be the primary source, methods must compensate farmers, minimize their burden, and be feasibly implemented.

Even if farmer data collection is put in place, these suggestions will serve the dual purpose of encouraging local food purchase and triangulating farmer-generated data.

- Work with local buyers to incorporate local product supply requirements into bids and requests for proposals within their procurement practices. Effective examples could be shared and tested elsewhere to develop a set of tools or lists of best practices.

- Building on the point above, work with state legislatures to require public institutions to annually report this information.

- Use the public relations power ("bully pulpit”) of local food advocates to publicly praise businesses that provide data.

\section{Conclusions}

The potential economic impact of increased consumption of locally grown food is of interest to policy makers and other stakeholders, yet to date little research has been conducted that estimates current consumption, a benchmark against which progress can be measured. This paper began by estimating the quantities of food, potential farmgate income, and number of acres needed to supply Vermont's current diet, as well as a diet in line with USDA dietary guidelines. We then developed and utilized a set of methods to measure current consumption of locally grown foods, and shared and discussed outcomes with an advisory committee of national experts. We were unable to gather data from several sources, creating a significant gap in our study. We then discussed the potential to use farm-level data to address key limitations.

Our study focuses on one state, but as discussed above, collaboration among states in a region would foster a smoother transition to a more localized and regionalized agricultural economy. The Northeast region has a track record of regional collaboration through the Northeast Sustainable Agriculture Working Group (NESAWG), whose mission is to "build a more sustainable, healthy, and equitable food system for our region" (Northeast Sustainable Agriculture Working Group, 2013). Using a community of practice like NESAWG is crucial to continue improving the methodology to measure local consumption and data collection robustness. Efforts to test and build on the methods discussed in this paper, and learn from others' work, are already underway.

The strengths of this paper include being the first attempt known to the authors to comprehensively measure this local food consumption statewide, as well as the degree of cooperation from stakeholders and the project advisory committee, which led to the lessons learned above and the opportunity to improve on this pilot effort. The weaknesses are the lack of data from the likely largest sources of local food and the other barriers discussed above. We hope our study assists scholars and practitioners elsewhere in their efforts and facilitates development of sound methods to address this important but difficult question.

\section{Acknowledgements}

We would like to thank the project advisory committee members for their expertise and support: Mike Hamm, Rich Pirog, Christian Peters, and Ken Meter. We would like to thank the anonymous reviewers for their helpful comments. Special thanks to Senator Patrick Leahy.

\section{References}

Abate, G., Conner, D., Hamm, M., Smalley, S., Thomas, B., \& Wright, D. (2009). Genesee county food system final report. East Lansing, Michigan: Michigan State University.

Andreatta, S., \& Wic-kliffe, W. (2002). Managing farmer and consumer expectations: A study of a North Carolina farmers market. Human Organization, 61(2), 167-176. 
Bean Smith, M., \& Sharp, J. S. (2008). A current and retrospective look at local food consumption and support among Obians (Social Responsibility Initiative Topical Report, Vol. 08-02). Columbus, Ohio: The Ohio State University. Retrieved from http://ohiosurvey.osu.edu/pdf/2008-local-foodstopical-report.pdf

Bellows, A., \& Hamm, M. (2001). Local autonomy and sustainable development: Testing import substitution in more localized food systems. Agriculture and Human Values, 18(3), 271-284. http://dx.doi.org/10.1023/A:1011967021585

Born, B., \& Purcell, M. (2006). Avoiding the local trap: Scale and food systems in planning research. Journal of Planning Education and Research, 26(2), 195-207. http://dx.doi.org/10.1177/0739456X06291389

Brown, C. (2003). Consumers' preferences for locally produced food: A study in southeast Missouri. American Journal of Alternative Agriculture, 18(4), 213 224. http://dx.doi.org/10.1079/AJAA200353

Colasanti, K., Cantrell, P., Cocciarelli, S., Collier, A., Edison, T., Doss, J.,...Smalley, S. (2010). Michigan good food charter. East Lansing, Michigan: C.S. Mott Group for Sustainable Food Systems at Michigan State University, Food Bank Council of Michigan, and the Michigan Food Policy Council. Available from: http://www.michiganfood.org

Conner, D., Cocciarelli, S., Mutch, B., \& Hamm, M. W. (2008). Community-based food systems in Michigan: Cultivating diverse collaborations from the ground up. Journal of Extension, 46(4), Article No. 4IAW1.

Conner, D., Colasanti, K., Ross, R. B., \& Smalley, S. B. (2010). Locally grown foods and farmers markets: Consumer attitudes and behaviors. Sustainability, 2(3), 742-756. http://dx.doi.org/10.3390/su2030742

Conner, D., Knudson, W., Hamm, M., \& Peterson, C. (2008). The food system as an economic driver: Strategies and applications for Michigan. Journal of Hunger \& Environmental Nutrition, 3(4), 371-383. http://dx.doi.org/10.1080/19320240802528849

Conner, D. S., \& Levine, R. (2007). Circles of association: The connections of community-based food systems. Journal of Hunger and Environmental Nutrition, 1(3), 5-25. http://dx.doi.org/10.1300/J477v01n03 02
Conner, D. S., Smalley, S. B., Colasanti, K. J. A., \& Ross, R. B. (2010). Increasing farmers market patronage: A Michigan survey. Journal of Food Distribution Research, 41(2), 26-35.

Feenstra, G. (2002). Creating space for sustainable food systems: Lessons from the field. Agriculture and Human Values, 19(2), 99-106. http://dx.doi.org/10.1023/A:1016095421310

Hinrichs, C. C. (2003). The practice and politics of food system localization. Journal of Rural Studies, 19(1), 33-45. http://dx.doi.org/10.1016/S07430167(02)00040-2

Hunt, A., \& Matteson, G. (2012). More than counting beans: Adapting USDA data collection practices to track marketing channel diversification. Journal of Agriculture, Food Systems, and Community Development, 2(4), 101-117. http://dx.doi.org/10.5304/jafscd.2012.024.010

Kingsolver, B. (2007). Animal, vegetable, miracle: A year of food life. New York: Harper Collins.

Kirschenmann, F., Stevenson, G. W., Buttel, F., Lyson, T. A., \& Duffy, M. (2008). Why worry about the agriculture of the middle? In T. A. Lyson, G. W. Stevenson \& R. Welsh (Eds.), Food and the mid-level farm: Renewing an agriculture of the middle. Boston: MIT Press.

Lev, L., \& Gwin, L. (2010). Filling in the gaps: Eight things to recognize about farm-direct marketing. Choices, 25(1). Retrieved from http://www.choicesmagazine.org/magazine/print. php?article $=110$

Lobao, L. M. (1990). Locality and inequality: Farm and industry structure and socioeconomic conditions. Albany, New York: State University of New York Press.

Low, S. A., \& Vogel, S. (2011). Direct and intermediated marketing of local foods in the United States (Economic Research Report No. ERR-128). Washington, D.C.: United States Department of Agriculture.

Lyson, T. A. (2004). Civic agriculture: Reconnecting farm, food, and community. Lebanon, New Hampshire: University Press of New England.

Lyson, T. A., \& Welsh, R. (2005). Agricultural industrialization, anticorporate farming laws, and rural community welfare. Environment and Planning A, 37(8), 1479-1491. http://dx.doi.org/10.1068/a37142 
Meter, K., \& Rosales, J. (2001). Finding food in farm country: The economics of food \& farming in southeast Minnesota. Minneapolis, Minnesota: Crossroads Resource Center. Retrieved from http://www.crcworks.org/?submit=fffc

Michigan State University Extension. (2004). Michigan availability guide. Retrieved from http://www.projectfresh.msu.edu/uploads/files/ 32/MI Availability Guide.pdf

Northeast Sustainable Agriculture Working Group. (2013). A 12-state network for regional food system development. Retrieved 14 Feb, 2013, Retrieved from http://www.nefood.org/page/nesawg

Oglethorpe, D. (2008). Local food - miles better? European Supply Chain Management, 1, 12-15.

Retrieved from http://www.europeansupplychainmanagement.co.

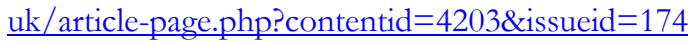

Ostrom, M. (2005). Consumer food purchasing: Interest in local and direct markets (CSANR Research Brief 2005-0207). Wenatchee, Washington: Washington State University.

Oxford University Press. (2007, November 12). Oxford word of the year: Locavore [Web log post].

Retrieved from http://blog.oup.com/2007/11/locavore/

Peters, C. J., Bills, N. L., Lembo, A. J., Wilkins, J. L., \& Fick, G. W. (2009). Mapping potential foodsheds in New York State: A spatial model for evaluating the capacity to localize food production. Renewable Agriculture and Food Systems, 24(1), 72-84. http://dx.doi.org/10.1017/S1742170508002457

Peters, C., Wilkins, J., \& Fick, G. (2007). Testing a complete-diet model for estimating the land resource requirements of food consumption and agricultural carrying capacity: The New York State example. Renewable Agriculture and Food Systems, 22(2), 145-153. http://dx.doi.org/10.1017/S1742170507001767

Pollan, M. (2008). Beyond the barcode: The local food revolution [Transcription of radio broadcast]. Santa Fe, New Mexico: Bioneers. Retrieved from http://store.bioneers.org/product p/2006-pollan.htm

Swenson, D. (2006). The economic impacts of increased fruit and vegetable production and consumption in Iowa: Phase II. Ames, Iowa: Leopold Center for Sustainable Agriculture, Iowa State University. Retrieved from http://www.leopold.iastate.edu/sites/default/files/pubsand-papers / 2006-05-economic-impacts-increased-fruitand-vegetable-production-and-consumption-iowa-phaseii.pdf

Swenson, D. (2010). Selected measures of the economic values of increased fruit and vegetable production and consumption in the upper Midwest. Ames, Iowa: Leopold Center for Sustainable Agriculture, Iowa State University. Retrieved from http://www.leopold.iastate.edu/ pubs-and-papers /2010-03-selected-measures

Thilmany, D., Bond, C., \& Bond, J. (2008). Going local: Exploring consumer behavior and motivations for direct food purchases. American Journal of Agricultural Economics, 90(5), 1303-1309. http://dx.doi.org/ 10.1111/j.1467-8276.2008.01221.x

Timmons, D., Wang, Q., \& Lass, D. (2008). Local foods: Estimating capacity. Journal of Extension, 46(5), Article No. 5FEA7. Retrieved from http://www.joe.org/joe/2008october/a7p.shtml

United Health Foundation. (2011). America's health rankings: Vermont: Diet, fruit \& vegetables: 2011. Retrieved from http://www.americashealth rankings.org/VT/diet/2011

United States Department of Commerce. (2009). 2010 nonemployer statistics: Vermont. Washington, D.C.: United State Census Bureau.

United States Department of Labor. (2010). Consumer expenditure survey. Washington, D.C.: Bureau of Labor Statistics.

United States Department of Agriculture [USDA]. (2007). Table 2. Market value of agricultural products sold including landlord's share and direct sales: 2007 and 2002, Vermont. Washington, D.C.: USDA National Agricultural Statistics Service.

USDA. (2009). 2007 census of agriculture. Washington, D.C.: Author

USDA. (2011). Fruits and vegetables (fresh weight equivalent): Per capita availability, 1970-2009. Washington, D.C.: Author.

Vermont Department of Taxes. (2010). Statistics Meals \& rooms multiple period report. Montpelier, Vermont: Author.

Vermont Sustainable Jobs Fund. (2011). Farm to plate initiative strategic plan (pp. 1-50). Montpelier, Vermont: Author.

Vermont Sustainable Jobs Fund. (2012). Farm to plate investment program 18 month report. Montpelier, Vermont: Author. 
Vermont Sustainable Jobs Fund Aggregation \& Distribution Working Group. (2012). Institutional local food purchase reporting. Montpelier, Vermont: Vermont Sustainable Jobs Fund.

Wright, W., Score, M., \& Conner, D. S. (2008). Food system makers: Motivational frames for catalyzing agri-food development through multi-stakeholder collaboration. Community Development, 38(3), 39-59. http://dx.doi.org/10.1080/15575330709489828

Zepeda, L., \& Leviten-Reid, C. (2004). Consumers' views on local food. Journal of Food Distribution Research, 35(3), 1-6. http://purl.umn.edu/27554

Zepeda, L., \& Li, J. (2006). Who buys local food? Journal of Food Distribution Research, 37(3), 1-11. http://purl.umn.edu/7064 